\title{
PENGARUH SKILL, PENGETAHUAN, DAN KARAKTERISTIK TERHADAP MINAT MAHASISWA AKUNTANSI UNTUK MENEMPUH PENDIDIKAN PROFESI AKUNTANSI
}

\author{
Tika Ratnawati \\ Sumaryanto
}

\begin{abstract}
Professional education is organized additional education after studying Strata one with intent to obtain a degree accountant, which aims to produce graduates who master the skill of the accounting profession and provide professional accounting competence. The main causes of accounting graduate students want to go to the Accounting Profession (PPAK) due to the various motivations they have. The purpose of this research is to investigate the influence of skills, knowledge, and characteristics of students interest in accounting for the accounting profession was educated at the University of Ahmad Dahlan Yogyakarta. Samples taken in this study using purposive sampling of students majoring in accounting semester V and VII, which already took a course auditing. The sample in this study 137 respondents Ahmad Dahlan University students. Variable are of interest to accounting students studying accountancy profession, skill, knowledge, and characteristics. Analysis using multiple regression analysis technique. Results of multiple regression analysis shows the level of the coefficient of determination (adjusted R2) of 0.050. This is the high percentage of variable skill, knowledge, and characteristics in explaining the variables of interest to accounting students studying accountancy profession at 5\% and the remaining 95\% is explained by variables or other factors outside the study. Based on the regression $F$ test to prove that there skiil influence, knowledge, and characteristics significantly to the interest of students studying accounting for the accounting profession is shown by the F probability value $<\alpha(0.05)$. Testing individuals ( $t$ test on regression) provide empirical evidence that the skills and knowledge that do not affect the interest of students to study accountancy profession dedicated to the probability value $t>\alpha(0.05)$, whereas only characteristics affect student interest in accounting for studying the accounting profession is shown by the probability value $t>\alpha(0.05)$.
\end{abstract}

Keywords: Skill, Knowledge, Characteristics, Accounting Profession, accountancy student interest to study the accounting profession

\section{PENDAHULUAN}

Pendidikan dalam kehidupan suatu negara memegang peranan sangat penting untuk menjamin kelangsungan hidup negara dan bangsa. Pendidikan merupakan wahana untuk meningkatkan dan mengembangkan kualitas sumber daya manusia. Menurut Undang-Undang Nomor 20 Tahun 2003 tentang Sistem Pendidikan 
Nasional menyatakan bahwa, pendidikan (pasal 1 ayat 1) adalah usaha sadar dan terencana untuk mewujudkan suasana belajar dan proses pembelajaran agar peserta didik aktif mengembangkan potensi diri untuk memiliki kekuatan spiritual keagamaan, pengendalian diri, kepribadian, kecerdasan, akhlak mulia serta keterampilan yang diperlukan dirinya, masyarakat, bangsa dan negara.

Pendidikan akuntansi di Indonesia sangat dibutuhkan oleh beberapa pihak, antara lain mahasiswa, pengguna jasa akuntan, maupun pihak perguruan tinggi. Maka aspek-aspek yang berkaitan dengan pendidikan akuntansi di perguruan tinggi perlu adanya perbaikan dan peningkatan kearah yang lebih baik. Seperti yang dikemukakan oleh Safford dan Kershaw (1998) dalam Machfoedz (1999) berpendapat bahwa institusi pendidikan tinggi harus melakukan transformasi secara struktural dan sistematis dengan melakukan pelatihan dan cara-cara lain untuk meningkatkan profesionalisme, baik terhadap staf akademik maupun non akademik. Kedua pakar tersebut juga berpendapat bahwa fungsi staf akademik sangat penting dalam membentuk suatu kelompok yang mampu melakukan perubahan-perubahan. Salah satu cara yang harus ditempuh oleh pendidikan tinggi adalah meningkatkan profesionalisme para pengajar di perguruan tinggi.

Pendidikan Profesi Akuntansi (PPAk) merupakan jenjang pendidikan tambahan yang ditujukan bagi seorang lulusan sarjana ekonomi jurusan akuntansi yang ingin mendapatkan gelar Akuntan. Surat Keputusan (SK) Mendiknas No. 179/U/2001 menyatakan bahwa lulusan sarjana Strata satu (S1) jurusan akuntansi berkesempatan menempuh PPAk di perguruan tinggi yang telah ditunjuk oleh Direktorat Jendral Pendidikan Tinggi. Mereka yang telah menempuh Pendidikan Profesi nantinya akan berhak memperoleh sebutan profesi Akuntan, dan juga semakin berpeluang meniti karir sebagai auditor pemerintahan, auditor internal, akuntan sektor publik, akuntan manajemen, akuntan pendidik, akuntan perpajakan, akuntan keuangan, maupun akuntan sistem informasi.

Sebelum SK tersebut dikeluarkan pada tahun 2001, pemberian gelar akuntan di Indonesia didasarkan pada Undang-Undang Nomor 34 Tahun 1954, yang menyatakan bahwa gelar akuntan diberikan pada lulusan perguruan tinggi negeri yang menempuh syarat untuk menghasilkan akuntan atas proses pendidikan yang 
diberikan. Untuk meraih gelar sarjana akuntansi, mahasiswa dari perguruan lainnya harus menempuh Ujian Negara Akuntansi (UNA). Seperti yang dikemukakan oleh Widyastuti, (2004) dalam Nurainah, (2008) proses perolehan gelar akuntan yang bersifat diskriminasi tersebut memiliki dua kelemahan yaitu timbulnya diskriminasi pemberian gelar akuntan dan tidak meratanya tingkat profesionalisme para akuntan di dunia kerja.

Alasan-alasan tersebut kemudian menyebabkan organisasi profesi akuntan (Ikatan Akuntan Indonesia) dan Departemen Pendidikan Nasional melalui Dirjen Dikti merasa perlu meninjau kembali peraturan yang berlaku untuk menghasilkan akuntan yang profesional. Melalui Surat Keputusan Menteri Pendidikan Nasional Nomor 179/U/2001 tentang penyelenggaraan PPAk, dan Surat Keputusan Mendiknas Nomor 180/P/2001 tentang panitia ahli persamaan ijazah akuntan, serta ditandatanganinya Nota Kesepahaman (MoU) pada tanggal 28 Maret 2002, antara Ikatan Akuntan Indonesia (IAI) dengan Dirjen Dikti Depdiknas atas pelaksanaan pendidikan profesi akuntan, yang pada akhirnya membuat PPAk di Indonesia dapat terealisasi.

Mahasiswa yang mengikuti PPAk adalah calon akuntan yang nantinya berhak mengikuti Ujian Sertifikasi Akuntan Publlik (USAP). Ujian ini merupakan syarat penting untuk mendapatkan ijin praktik sebagai akuntan publik. Dengan mengikuti ujian ini, diharapkan calon akuntan di masa depan tidak hanya mahir secara teknis namun juga mahir secara profesional. Dengan demikian, lulusan PPAk nantinya akan memiliki daya saing sebagai akuntan yang lebih tinggi dibandingkan dengan sarjana ekonomi dari jurusan akuntasi yang tidak mempunyai predikat akuntan (Nurainah, 2008).

Pendidikan akuntansi yang menghasilkan akuntan dari perguruan tinggi merupakan produk hasil proses belajar mengajar. Salah satu indikator peningkatan profesionalisme adalah adanya kurikulum yang memadai dan adanya standar profesionalisme melalui ujian profesi. Machfoedz (1998) mengemukakan bahwa profesionalisme ditandai dengan adanya tiga indikator yaitu: skill, pengetahuan (knowledge), karakter (charakter). Ketiga indikator tersebut bisa diberikan kepada calon akuntan selama mereka menempuh mata kuliah di perguruan tinggi. Semua 
mata kuliah yang membentuk profesionalisme tersebut harusnya diakomodasikan dalam kurikulum. Kurikulum yang ada saat ini dianggap oleh banyak pakar akuntansi masih sangat kurang memadai (Novin and Tucker, 1993; Dennis and Turner, 1995: serta Siegel dan Kulesza, 1995 dalam Machfoedz 1998).

Pendidikan akuntansi awalnya diatur dalam Undang-Undang Nomor 034 Tahun 1954 yang menyatakan bahwa yang berhak menyandang gelar sebagai akuntan adalah lulusan Perguruan Tinggi Negeri yang telah ditetapkan serta telah mendaftar ke Departemen Keuangan untuk mendapatkan registrasi negara sebagai lulusan Perguruan Swasta harus mengikuti Ujian Nasional Akuntansi terlebih dahulu. Pendidikan profesi sebagai pendidikan sarjana mulai diatur dengan dikeluarkannya SK Menteri Pendidikan dan Kebudayaan Nomor 036 Tahun 1993 tetapi pada saat itu pendidikan akuntansi masih belum memisahkan antara pendidikan gelar dan pendidikan profesi. Hal tersebut membuat para lulusan tidak menyadari pentingnya pendidikan profesi tersebut, karena mereka berpendapat bahwa meskipun menempuh pendidikan profesi, perlakuannya akan tetap sama dengan lulusan sarjana tanpa profesi. Pemikiran tentang tidak pentingnya pendidikan profesi akuntan bertambah dengan adanya SK Mendikbud Nomor 031/U/1994 yang tidak lagi mengatur tentang pendidikan profesi, bahkan kurikulum nasional tahun 1994 memberikan ketidakjelasan semakin membuat profesi akuntansi perlu mendapatkan legalitas yang pasti.

Menindaklanjuti ketidakjelasan serta adanya kesadaran tentang pendidikan profesi bagi lulusan akuntansi, maka dikeluarkan berdasarkan Undang-Undang Nomor 34 Tahun 1994 dan Keputusan menteri pendidikan dan kebudayaan Nomor 03110/U/1994 mengenai pemberian sebutan akuntan yang bisa diperoleh setelah mahasiswa menyelesaikan pendidikan profesi (Machfoedz, 1998). Kemudian dikeluarkan SK Mendikbud Nomor 56 Tahun 1999 yang memuat tentang pendidikan profesi akuntansi. Fenomena baru lagi muncul ketika dikeluarkan Surat keputusan Menteri Pendidikan Nasional Republik Indonesia Nomor 179/U/2001 tentang Penyelenggraan PPAk dan surat kesepakatan Mendiknas No 180/P/2001, tentang Pengangkatan Panitia Ahli Persamaan Ijazah Akuntan, kesepakatan ini ditandatangani antara IAI dengan Dirjen Dikti Depdiknas tanggal 28 Maret 2002 
(Kholis, 2003 dalam Irmawati, 2008). Dengan adanya SK tersebut, maka akan semakin jelas pentingnya menempuh Pendidikan Profesi Akuntansi (PPAk).

Penelitian ini dilakukan untuk mengetahui bagaimana minat mahasiswa akuntansi dalam memilih untuk menempuh pendidikan profesi akuntansi sehubungan dengan adanya pengaruh skill, pengetahuan (knowledge), dan karakteristik (charakteristic) menurut minat mahasiwa untuk menempuh profesi akuntansi sehubungan dengan adanya pendidikan dalam profesi akuntan.

\section{PENGEMBANGAN HIPOTESIS}

Berdasarkan Surat Keputusan (SK) Mendiknas Nomor 179/U/2001, pertimbangan pembukaan Pendidikan Profesi Akuntansi adalah sebagai berikut:

a. Pertimbangan kegiatan akuntansi menuntut ketersediaan tenaga kerja ahli yang berkualitas di bidang akuntansi.

b. Perkembangan pendidikan akuntansi tingkat nasional bagi program sarjana (SI) telah sampai pada tingkat yang dimungkinkan dibukanya jalur Pendidikan Profesi akuntan.

Penelitian Irmawati (2008) bahwa penelitian tersebut skill berpengaruh pada minat mahasiswa akuntansi dalam menempuh profesi akuntansi. Dengan adanya kepemilikan skill, seorang akuntan mampu menjadi seorang akuntan yang profesional. Berdasar uraian diatas dapat diajukan hipotesis sebagai berikut:

H1: Skill berpengaruh terhadap minat mahasiswa akuntansi untuk menempuh pendidikan profesi akuntansi

Pengetahuan (knowledge) didefinisikan sebagai pemahaman seorang mahasiswa akuntansi terhadap suatu hal. Menurut Novin dan Tucker (1993) dalam Mahfoedz (1999), pengetahuan dapat duikur dengan adanya general skill (pengetahuan umum), accounting education (pengetahuan tentang akuntansi dan pendidikannya), serta bisnis education (pengetahuan tentang bisnis). Dengan adanya pengetahuan yang banyak maka minat mahasiswa untuk menempuh pendidikan profesi akuntansi akan bertambah tinggi. Karena mahasiswa akuntansi merasa mampu untuk menempuh pendidikan profesi akuntansi tersebut. Berdasar uraian diatas dapat diajukan hipotesis sebagai berikut: 
H2: Pengetahuan (knowledge) berpengaruh terhadap minat mahasiswa akuntansi untuk menempuh pendidikan profesi akuntansi

Karakteristik didefinisikan sebagai kepribadian khusus sesuai dengan perwatakan tertentu yang dimiliki oleh seorang mahasiswa akuntansi. Menurut Novin dan Tucker (1993) dalam Mahfoedz (1999) karakter diukur dengan commen sense, etika, motivasi, professional attitude, confidence (kepercayaan diri), professional appearance, pleasent personality, assertiveness, dan leardership (kepemimpinan).

Seorang akuntan harus mempunyai sikap tanggung jawab terhadap moral, jiwa kepemimpinan, bergairah dalam beraktivitas, pemikiran kreatif, sikap presistansi kekuatan diri dan mempunyai intergritas yang tinggi. Dengan adanya sikap tersebut dapat menimbulkan minat mahasiswa untuk menempuh pendidikan akuntansi. Berdasar uraian diatas dapat diajukan hipotesis sebagai berikut:

H3: Karakteristik (charakteristic) berpengaruh terhadap minat mahasiswa akuntansi untuk menempuh pendidikan profesi akuntansi

Adapun hubungan ketiga elemen di atas sangat berpengaruh penting dalam minat mahasiswa dalam menempuh pendidikan profesi akuntansi. Dengan demikian halnya bagi seorang akuntan. Ini dimaksudkan agar seorang akuntan mampu bersaing memenangkan persaingan tersebut dengan akuntan asing. PPAk sendiri merupakan cara untuk memperdalam skill, pengetahuan, dan karakteristik menurut kemampuan dalam akuntansi.

\section{METODA PENALITIAN}

\section{Populasi dan Sampel}

Populasi dalam penelitian ini adalah mahasiswa-mahasiswi yang melanjutkan program studi ke jenjang S1 di Perguruan Tinggi Yogyakarta. Sampel adalah bagian dari jumlah dan karakteristik yang dimiliki oleh populasi tersebut (Sugiyono, 1999). Sampel dalam penelitian ini adalah mahasiswa-mahasiswi Perguruan Tinggi Swasta Muhammadiyah yaitu Universitas Ahmad Dahlan yang telah duduk di semester V dan semester VII. 
Penentukan sampel dalam penelitian ini, peneliti menggunakan metode nonprobability sampling, yaitu purposive sampling. Ada dua jenis yaitu pemilihan sampel berdasarkan pertimbangan dan berdasarkan kuota. Penelitian ini digunakan teknik sampling kuota. Sampling kuota adalah teknik untuk menentukan sampel dari populasi yang mempunyai ciri-ciri tertentu sampai jumlah (kuota) yang diinginkan (Sugiyono, 1998) yaitu mahasiswa akuntansi yang menduduki semester V dan VII. Alasan pemilihan kriteria tersebut adalah:

a. Mahasiswa yang duduk pada semester V dan VII sudah mendekati kelulusan

b. Mahasiswa pada semester tersebut sudah memahami etika profesional akuntan dengan baik.

Data primer dalam penelitian ini diperoleh dengan cara menyebar kuesioner secara langsung pada mahasiswa-mahasiswi Universitas Ahmad Dahlan yang duduk di semester V dan VII. Penyebaran kuesioner secara langsung dimaksudkan untuk mendapatkan data yang lebih akurat dan tanggapan responden yang lebih tepat. Penyebaran data kuesioner yang telah diserahkan kepada responden akan diambil sendiri oleh peneliti sesuai dengan kesepakatan antara responden dengan peneliti.

\section{Variabel Penelitian dan Teknik Pengambilan Keputusan}

1. Variabel independen

Variabel independen dalam penelitian ini adalah skill, pengetahuan (knowledge), dan karakteristik (characteristic).

2. Variabel dependen

Variabel dependen dalam penelitian ini adalah minat. Skala Likert digunakan untuk mengukur keahlian, pengetahuan, dan karakteristik terhadap minat mahasiswa akuntansi untuk menempuh Pendidikan Profesi Akuntansi. Dengan skala Likert, maka variabel yang akan diukur dijabarkan menjadi indikator variabel. Kemudian indikator tersebut dijadikan sebagai titik tolak untk menyusun item-item instrumen yang dapat berupa pernyataan atau pertanyaan. Kuesioner yag diberikan kepada responden terdiri dari 36 pertanyaan. Pertanyaan tersebut terdiri dari 
elemen-elemen untuk menempuh pendidikan profesi akuntansi meliputi skill, pengetahuan (konwledge), karakteristik (characteristic), dan minat mahasiswa.

\section{Teknik Analisis Data}

\section{Analisis Deskriptif}

Analisis deskriptif yaitu analisis tentang karakteristik dari suatu keadaan dari objek yang diteliti. Analisis ini mengemukakan data-data responden seperti karakteristik responden yang meliputi: jenis kelamin, umur, semester sekarang, dan angkatan tahun masuk.

\section{Uji Validitas}

Uji validitas menunjukkan suatu alat pengukur itu mengukur sesuatu yang ingin diukur. Penelitian ini peneliti menggunakan kuesioner. Suatu koesioner dikatakan valid jika pernyataan tersebut mengukur apa yang seharusnya diukur (Indriantoro dan Supomo, 2002). Uji validitas data didapat dengan melihat nilainilai pearson correlation. Pengujian dilakukan dengan melihat angka koefisien kolerasi (r hitung) yang menyatakan hubungan antar skor pernyataan dengan skor total (item correlation). Hasilnya kita bandingkan dengan rtabel dimana $\mathrm{df}=\mathrm{n}-2$ dengan taraf signifikan 5\%. Jika nilai item kolerasi > r tabel maka dapat dikatakan valid.

\section{Uji Reliabilitas}

Uji reliabilitas digunakan untuk mengetahui alat ukur mampu melakukan pengukuran secara konsisten. Suatu kuesioner dikatakan reliabel jika pertanyaan tersebut digunakan beberapa kali untuk mengukur objek yang sama, akan menghasilkan data yang sama (Indriantoro dan Supomo, 2002). Pengujian reliabilitas dilakukan setelah analisis validitas dilakukan, analisis reliabilitas dilakukan dengan Cronbach's alpha, yaitu koefisien reliabilitas yang menunjukkan seberapa baik item suatu instrumen berkorelasi positif dengan item yang lainnya. Semakin tinggi korelasi alpha, berarti semakin baik pengukuran suatu instrumen. Suatu instrumen peneliti dikatakan reliabel apabila nilai alpha $>0,60$. 


\section{Uji Asumsi Klasik}

\section{a. Uji normalitas}

Uji normalitas ini bertujuan untuk menguji apakah model regresi variabel penganggu atau residual, memiliki distribusi normal (Ghozali, 2009). Cara yang digunakan dalam mendeteksi apakah residual berdistribusi normal atau tidak dengan analisis grafik normal plot. Jika data menyebar disekitar garis diagonal dan mengikuti arah garis diagonal maka model regresi memenuhi asumsi normalitas. Jika data menyebar jauh dari diagonal atau tidak mengikuti arah garis diagonal, maka model regresi tidak memenuhi asumsi normalitas.

\section{b. Uji multikolinieritas}

Uji multikolinieritas bertujuan untuk menguji pada model regresi ditemukan adanya kolerasi antara variabel independen. Jika antar variabel independen ada kolerasi yang cukup tinggi atau diatas 90\%, maka hal ini merupakan indikasi adanya multikolinearitas (Ghozali, 2009). Ada tidaknya multikolinieritas dapat dilihat pada nilai variance inflation factor (VIF). Jika nilai variance inflation factor (VIF) tidak melebihi 10 maka tidak terjadi gejala multikolinearitas, tetapi jika VIF melebihi 10 maka terjadi multikolinearitas (Ghozali, 2009)

\section{c. Uji heteroskedastisitas}

Uji heteroskedastisitas bertujuan untuk menguji model regresi terjadi ketidaksamaan dari residual satu pengamatan ke pengamatan yang lain tetap, maka disebut homokedastisitas dan jika berbeda disebut heteroskedastisitas. Jika regresi tidak lolos uji heteroskedastisitas maka varian standar error akan bias, akibatnya uji tidak dapat dipercaya sehingga tidak bisa diambil satu kesimpulan. (Ghozali, 2009).

Cara yang dipilih untuk mendeteksi ada tidaknya gangguan heteroskedastisitas pada model regresi dalam penelitian ini adalah dengan menggunakan grafik plot. Apabila pada grafik plot terlihat pola tertentu seperti bergelombang, melebar atau menyempit berarti terjadi heteroskedastisitas. Jika tidak ada pola yang jelas, serta titik-titik tidak menyebar diatas dan di bawah angka 0 pada sumbu Y, maka tidak terjadi heteroskedastisitas (Ghozali, 2009). 


\section{d. Uji Autokorelasi}

Uji autokorelasi berarti terjadi kolerasi antara anggota sampel yang diukur berdasarkan waktu penyimpangan ini biasanya muncul pada observasi yang menggunakan data time saries. Ada tidaknya autokorelasi dideteksi dengan menggunakan Durbin Watson test. Pengujian autokolerasi ini, diharapkan tidak ada autokorelasi baik positif maupun negatif. Kriteria pengujian autokorelasi tersebut tertera pada tabel berikut (Ghozali, 2009):

\begin{tabular}{|c|c|c|}
\hline Jika & Keputusan & Hipotesis nol \\
\hline $0<\mathrm{d}<\mathrm{dl}$ & Tolak & Tidak ada autokorelasi positif \\
\hline $\mathrm{d} l \leq \mathrm{d} \leq \mathrm{du}$ & No decision & Tidak ada autokorelasi positif \\
\hline $4-\mathrm{dl}<\mathrm{d}<4$ & Tolak & Tidak ada autokorelasi negatif \\
\hline $4-\mathrm{du} \leq \mathrm{d} \leq 4-\mathrm{dl}$ & No decision & Tidak ada autokorelasi negatif \\
\hline $\mathrm{du}<\mathrm{d}<4-\mathrm{du}$ & Tidak ditolak & Tidak ada autokorelasi, positif atau negatif \\
\hline
\end{tabular}

\section{Uji Hipotesis}

\section{a. Regresi Linier Berganda}

Pengujian hipotesis pertama hingga hipotesis ketiga menggunakan analisis regresi linier berganda. Dengan persamaan sebagai berikut:

$\mathrm{Y}=\beta_{0}+\beta \mathrm{X}_{1}+\beta \mathrm{X}_{2}+\beta \mathrm{X}_{3}+\mathrm{e}$

Keterangan:

$\mathrm{Y}=$ Minat mahasiswa untuk menempuh pendidikan PPAk

$\mathrm{X}_{1} \quad=$ Skill

$\mathrm{X}_{2} \quad=$ Pengetahuan

$\mathrm{X}_{3}=$ Karakteristik

$\mathrm{B}_{0} \quad=$ Konstanta

$\mathrm{e} \quad=$ Error term

\section{b. Uji t}

Pengujian ini dimaksud untuk mengetahui pengaruh masing-masing variabel independen terhadap variabel dependen (Ghozali, 2009). Langkah-langkah dalam pengujian hipotesisnya adalah menentukan dasar pengambilan keputusan dan menarik kesimpulan dengan tarif signifikansi $(\alpha)$ sebesar 5\% atau 0,05 dengan dasar apabila jika tingkat signifikansi $<\alpha=0,05$, dan nilai koefisien regresi positif, 
maka $\mathrm{H}_{0}$ ditolak dan Ha diterima. Sebaliknya jika tingkat signifikansi $>\alpha=0,05$ maka Ho diterima dan Ha ditolak.

\section{c. Uji F}

Pengujian ini dimaksudkan untuk mengetahui pengaruh secara bersama-sama variabel independen terhadap variabel dependen (Ghozali, 2009). Langkah-langkah dalam pengujian hipotesisnya adalah dasar pengambilan keputusan dan menarik kesimpulan dengan tarif signifikan $(\alpha)$ sebesar 5\% atau 0,05 dengan dasar jika tingkat signifikansi $<\alpha=0,05$ maka, Ho ditolak dan Ha diterima. Sebaliknya jika tingkat signikansi $>\alpha=0,05$ maka Ho diterima dan Ha ditolak.

Dari analisis regresi berganda diperoleh nilai koefisien determinasi $\left(\mathrm{R}^{2}\right)$. Koefisien determinasi menunjukkan seberapa besar variabel independen dapat menjelaskan variabel dependen. Karena penelitian ini menggunakan variabel independen lebih dari dua maka lebih tepat jika peneliti menggunakan adjusted $\mathrm{R}^{2}$ sebagai koefisien deternimasi.

\section{HASIL ANALISIS DATA}

\section{Pengujian Validitas dan Realiabilitas}

Pengujian dilakukan dengan melihat angka koefisien korelasi ( $\mathrm{r}$ hitung) yang menyatakan hubungan antara skor pernyataan dengan skor total (item correlation). Hasilnya kita bandingkan dengan $\mathrm{r}$ tabel dimana $\mathrm{df}=\mathrm{n}-2$ dengan taraf signifikansi 5\%. Jika nilai item korelasi > $\mathrm{r}$ tabel maka dapat dikatakan valid. Pengujian reliabilitas dilakukan dengan teknik Cronbach's alpha dengan jumlah responden 137. Suatu instrumen penelitian dinyatakan reliabel apabila nilai alpha $>0,60$.

\section{Pengujian Asumsi Klasik}

\section{Uji Normalitas}

Berdasarkan hasil analisis grafik, data menyebar di sekitar garis diagonal dan mengikuti arah garis diagonal. Hal ini berarti semua data dalam penelitian ini berdistribusi normal dan model regresi layak digunakan dalam penelitian ini. 


\section{Uji Multikolinieritas}

Tabel 2

Hasil Uji Multikolinearitas

\begin{tabular}{|c|c|c|l|}
\hline Variabel & Tolerance & VIF & Keterangan \\
\hline Skill $\left(\mathrm{X}_{1}\right)$ & 0,660 & $\begin{array}{c}1,51 \\
4\end{array}$ & Tidak ada multikolinieritas \\
\hline $\begin{array}{c}\text { Pengetahuan } \\
\left(\mathrm{X}_{2}\right)\end{array}$ & 0,618 & $\begin{array}{c}1,61 \\
7\end{array}$ & Tidak ada multikolinieritas \\
\hline $\begin{array}{c}\text { Karakteristik } \\
\left(\mathrm{X}_{3}\right)\end{array}$ & 0,617 & $\begin{array}{c}1,62 \\
0\end{array}$ & Tidak ada multikolinieritas \\
\hline
\end{tabular}

Sumber : Data primer, diolah (2010)

Berdasar tabel 1 nilai tolerance masing-masing variabel tidak ada yang lebih kecil dari 0,1 dan tidak ada nilai VIF lebih dari 10. Hal ini menunjukkan bahwa penelitian tidak terjadi multikolinieritas antara variabel independen, sehingga model regresi layak digunakan.

\section{Uji Heteroskedastisitas}

Hasil uji heteroskedastisitas dengan menggunakan grafik scatterplot terlihat titik-titik menyebar secara acak, tersebar baik di atas maupun di bawah angka 0 pada sumbu Y. Hal ini berarti dalam model regresi tidak terjadi heteroskedastisitas.

\section{Uji Autokorelasi}

Durbin Watson pada tingkat kesalahan $\alpha=5 \%$ dan $N=137$ serta variabel independen yang mempengaruhi variabel dependen $\mathrm{k}=4$, maka dapat diketahui nilai dl dan du yaitu $\mathrm{dl}=1,661$ dan $\mathrm{du}=1,781$ sehingga batasan autokorelasi menjadi seperti yang terlihat pada tabel 2 .

\section{Tabel 2}

Pengambilan Keputusan Ada Tidaknya Autokorelasi

\begin{tabular}{|c|c|c|}
\hline Jika & Keputusan & Hipotesis nol \\
\hline $0<\mathrm{d}<1,661$ & Tolak & Tidak ada autokorelasi positif \\
\hline $1,661 \leq \mathrm{d} \leq 1,781$ & No decision & Tidak ada autokorelasi positif \\
\hline $4-1,661<\mathrm{d}<4$ & Tolak & Tidak ada autokorelasi negatif \\
\hline $4-1,781 \leq \mathrm{d} \leq 4-1,661$ & No decision & Tidak ada autokorelasi negatif \\
\hline $1,781<\mathrm{d}<4-1,781$ & Tidak ditolak & $\begin{array}{c}\text { Tidak ada autokorelasi, positif } \\
\text { atau negatif }\end{array}$ \\
\hline
\end{tabular}

Sumber: Data primer, diolah (2010) 
Ada tidaknya autokorelasi dapat dilakukan dengan membandingkan nilai Durbin Watson hitung yang diperoleh dari hasil regresi dan nilai Durbin Watson sebesar 2,286. Dengan menggunakan pertimbangan parameter tersebut nilai Durbin Watson terletak pada posisi $1,781<\mathrm{d}<4-1,781$. Dengan demikian, hasil pengujian model regresi mengandung autokorelasi. Autokorelasi dalam penelitian ini tidak bisa dihilangkan setiap ingin dihilangkan nilai Durbin Watson semakin tinggi, oleh karena itu perlu adanya penambahan variabel independen yang dapat mempengaruhi variabel dependen agar hasil penelitian menimbulkan tidak adanya autokorelasi.

\section{Pengujian Hipotesis}

\section{Uji Koefisien Determinasi}

Berdasar analisis regresi tersebut dapat diketahui nilai koefisien determinasi (adjusted $R^{2}$ ) sebesar 0,050. Hal ini menunjukkan bahwa besarnya persentase variabel skill, pengetahuan, dan karakteristik dalam menjelskan variabel minat mahasiswa akuntansi untuk menempuh pendidikan profesi akuntansi sebesar 5\% dan sisanya sebesar $95 \%$ dijelaskan oleh variabel atau faktor lain di luar penelitian.

\section{Uji F}

Hasil analisis regresi linier berganda pada menunjukkan nilai F sebesar 3,371 dan signifikansi sebesar 0,020. Karena taraf signifikansi lebih kecil dari $\alpha(0,05)$ maka hasil pengujian menunjukkan secara bersama-sama variabel skill, pengetahuan, dan karakteristik mempunyai pengaruh terhadap minat mahasiswa akuntansi untuk menempuh pendidikan profesi akuntansi.

\section{Uji t}

Tabel 3

Hasil Analisis Regresi Berganda

\begin{tabular}{|c|c|c|c|}
\hline Variabel & Koefisien & t hitung & Sig t \\
\hline Konstanta & 14,081 & & \\
\hline Skill & 0,081 & $-0,870$ & 0,386 \\
\hline Pengetahuan & 0,087 & $-1,401$ & 0,164 \\
\hline Karakteristik & 0,404 & 3,176 & 0,002 \\
\hline
\end{tabular}

Sumber : Data primer, diolah (2010) 
Uji t pada regresi atau uji secara individual dimaksudkan untuk mengetahui pengaruh dari masing-masing variabel independen terhadap variabel dependen. Berdasar hasil perhitungan pada tabel, maka dapat diketahui sebagai berikut:

\section{a. Skill terhadap minat mahasiswa akuntansi}

Berdasar hasil uji statistik, skill mempunyai nilai signifikansi sebesar 0,386 lebih kecil dari tingkat signifikansi 5\%. Sehingga kriteria pengujian hipotesis dinyatakan $\mathrm{Ho}_{1}$ diterima dan $\mathrm{Ha}_{1}$ ditolak artinya, variabel skill tidak berpengaruh secara signifikan terhadap minat mahasiswa akuntansi untuk menempuh pendidikan profesi akuntansi.

\section{b. Pengetahuan terhadap minat mahasiswa akuntansi}

Berdasarkan hasil uji statistik, pengetahuan mempunyai nilai signifikansi sebesar 0,164 lebih besar dari tingkat signifikansi 5\%. Sehingga kriteria pengujian hipotesis dinyatakan $\mathrm{Ho}_{2}$ diterima dan $\mathrm{Ha}_{2}$ ditolak artinya, variabel pengetahuan tidak berpengaruh secara signifikan terhadap minat mahasiswa akuntansi untuk menempuh pendidikan profasi akuntansi.

\section{c. Karakteristik terhadap minat mahasiswa akuntansi}

Berdasarkan hasil uji statistik, karakteristik mempunyai nilai signifikansi sebesar 0,002 lebih kecil dari tingkat signifikansi 5\%. Sehingga kriteria pengujian hipotesis dinyatakan $\mathrm{Ho}_{3}$ ditolak dan $\mathrm{Ha}_{3}$ diterima artinya, variabel karakteristik berpengaruh secara signifikan terhadap minat mahasiswa akuntansi untuk menempuh pendidikan profesi akuntansi.

\section{SIMPULAN}

Berdasarkan hasil analisis data dalam penelitian ini, maka diperoleh simpulan bahwa skill, pengetahuan, dan karakteristik berpengaruh secara silmutan terhadap minat mahasiswa akuntansi untuk menempuh pendidikan profesi akuntansi. Secara parsial, hanya karakteristik yang berpengaruh terhadap minat mahasiswa akuntansi untuk menempuh pendidikan profesi akuntansi. Sedangkan skill dan pengetahuan tidak berpengaruh secara parsial terhadap minat mahasiswa akuntansi untuk menempuh pendidikan profesi akuntansi. 


\section{DAFTAR PUSTAKA}

Asmita, Emita Wahyu, 2001. Faktor-faktor yang Berpengaruh dalam Pemilihan Profesi Akuntansi Publik dan Non Publik Bagi Mahasiswa Jurusan Akuntansi. KOMPAK. No.1 Januari 2001, hal 57-84.

Depdiknas. 1995. Kamus Besar Indonesia. Edisi Kedua. Jakarta: Balai Pustaka. 2001. Kamus Besar Indonesia. Jakarata: Balai Pustaka.

Gujarati, Damodar. 1995. Ekomatrika Dasar. Alih Bahasa Indonesia Zien Sumarno. Jakarta: Erlangga.

Ghozali, Imam. 2009. Statistik Multivariete. Semarang: Penerbit Badan Penerbit Universitas Diponegoro.

Indriantoro, Nur dan Bambang Supomo. 2002. Metode Peneltian Bisnis untuk Akuntansi dan Manajemen. Yogyakarta: BPFE-Yogyakarta.

Irmawati, Tunjung. 2008. Pengaruh Tuntutan Profesionalisme di Era Globalisasi terhadap Minat Mahasiswa untuk Menempuh Pendidikan Profesi Akuntansi. Surakarta: Universitas Muhammadiyah Surakarta.

Istiwiyanti, Sujarwo. 1991. Psikologi Perkembangan Sistem Pendidikan Sepanjang Kehidupan. Terjemahan Child Development. Jakarta: Erlangga.

Kurniawati, Indah. 2006. Modul Pengolahan Data Elektronik. Yogyakarta: Universitas Ahmad Dahlan.

Kurniawati, Indriani Budi. 2003. Faktor-Faktor yang Mempengaruhi Minat Mahasiswa Jurusan Akuntansi FE UNS untuk Mengikuti Pendidikan Profesi Akuntansi (PPA). Skripsi. Fakultas Ekonomi UNS.

Keputusan Menteri Nasional Republik Indonesia No. 179/UU/2001 tentang Penyelenggaraan Pendidikan Profesi Akuntansi

Machfoedz, Mas'ud. 1998. "Survey Minat Mahasiswa untuk mengikuti Ujian Sertfikat Akuntan Publik". Jurnal Ekonomi dan Bisnis Indonesia, Vol 13 No. 4. hal 110-124. 
Machfoedz, Mas'ud. 1999. "Studi Persepsi Mahasiswa Terhadap Profesionalisme Dosen Akuntansi Perguruan Tinggi". Jurnal Akuntansi dan Auditing Indonesia, Vol 3, No 1, FE UII, Yogyakarta.

Nurainah Lisnasari, Riani, 2008. "Faktor-Faktor yang Mempengaruhi Minat mahasiswa Akuntansi untuk Mengikuti Pendidikan Profesi Akuntansi (PPAk)". Jurnal ekonomi dan Bisnis Indonesia (November). Hal 1-2.

Septi Wulansari, Amilia. 2008. Studi Persepsi Mahasiswa Akuntansi terhadap Profesonalisme Dosen Akuntansi Perguruan Tinggi di Daerah Istimewa Yogyakarta. Skripsi. Yogyakarta: Universitas Islam Indonesia.

SK menteri Pendidikan dan Kebudayaan No. 036 tahun 1993 Tentang Pemberian Sebutan Akuntan

Sudarmanto, R Gunawan. 2005. Analisis Regresi Linier Ganda dengan SPSS. Yogyakarta: Ghalia Ilmu.

Sugiyono. 1999. Metode penelitian Bisnis. Bandung: CV. Alvabeta. 